International Journal of Agriculture and Environmental Research

ISSN: 2455-6939

Volume: 06, Issue: 01 "January-February 2020"

\title{
EFFECT OF DIFFERENT MULCHES ON GROWTH AND YIELD OF TOMATO
}

\author{
M. R. Islam ${ }^{1}$, M. G. Kibria ${ }^{2}$, A. K. Das ${ }^{1}$ and S. D. Setu ${ }^{1}$ \\ ${ }^{1}$ Scientific Officer, Bangladesh Agricultural Research Institutre, RARS, Barishal-8211 \\ ${ }^{2}$ Principal Scientific Officer, Bangladesh Agricultural Research Institutre, RARS, Barishal-8211 \\ DOI: 10.46609/IJAER.2020.v06i01.007 URL: https://doi.org/10.46609/IJAER.2020.v06i01.007
}

\begin{abstract}
The study was conducted at the experimental field of horticulture division, RARS, Rahmatpur, Barishal during the winter season of 2018-19 to determine the effect of various mulches on growth and yield of tomato. The treatments of the experiment comprised five mulch materials viz. Sawdust (5cm thick), Cocodust (5cm thick), Rice husk (5cm thick), Water hyacinth (chopping and $10 \mathrm{~cm}$ thick), Black Ploythene with no mulch as control and BARI Tomato 15 as a variety. Mulching significantly increased the total number of fruit/plant of tomato over bare plants. The highest number of fruit was recorded in chopped Water hyacinth mulch (28.74) and the lowest was in treatment control i.e. no mulch (22.80). Similar trend was found in single fruit weight, being the highest in chopped Water hyacinth mulch $(66.24 \mathrm{~g})$ lowest was in cocodust mulch (53.26g). The highest yield was recorded in chopped Water hyacinth mulch (94.96t/ha) followed by rice husk mulch $(81.84 \mathrm{t} / \mathrm{ha})$ and the lowest was in control i.e. no mulch $(62.86 \mathrm{t} / \mathrm{ha})$. From $1^{\text {st }}$ year experiment, the study reveals that BARI Tomato 15 can be cultivated using chopping water hyacinth as a mulch material for higher yield.
\end{abstract}

Keywords: Tomato, Mulch, Growth and Yield

\section{INTRODUCTION}

Tomato (Lycopersicon esculentum) is one of the popular vegetables extensively grown during the winter season in Bangladesh. It is drawing attention of the growers and consumers and made its position among the cultivated vegetables. It contributes significantly to the nutrition of the people as a source of vitamins and minerals. In Bangladesh, congenial atmosphere remains for tomato production during November to March. It is mainly grown in winter season. Among various factors responsible for higher yield, supply of nutrient and availability of moisture play 
vital role in the production and quality of tomato. Its production can be increased by adopting improved cultural practices. Mulching is the effective means to reduce weed infestation and conserve moisture in the root zone. This practice also encourages deeper and denser rooting. Mulches have been found to decrease soil moisture losses by reducing soil temperature and evaporation, promoting favorable soil biotic activities, reducing hard soil setting and contributing plant nutrients (A. R. Pal et al., 1994; H. S. Bhella, 1994; R. C. Chakraborty, 1994, R. S. Hooda, 1999). Mulching has also been identified by many workers as a method to provide a favourable soil environment by minimizing crusting at the soil surface and keep it stable (A. P. Mehta, 1973). Little information regarding mulching on tomato cultivation in the southern area is available. Therefore, the present study was conducted to determine the effect of various mulches on growth and yield of tomato.

\section{MATERIALS AND METHODS}

The experiment was conducted during 2018-19 at Regional Agricultural Research Station, Rahmatpur, Barishal. The treatments of the experiment comprised five mulch materials viz. Sawdust ( $5 \mathrm{~cm}$ thick), Cocodust ( $5 \mathrm{~cm}$ thick), Rice husk ( $5 \mathrm{~cm}$ thick), Water hyacinth (chopping and $10 \mathrm{~cm}$ thick), Black Ploythene with no mulch as control and BARI Tomato 15 as a variety. The experimental design was randomized complete block design (factorial) with three replications. Unit plot size was $4.8 \mathrm{~m} \times 1 \mathrm{~m}$. The seedlings were transplanted on the $24^{\text {th }}$ October, 2018 maintaining a spacing $60 \mathrm{~cm} \times 40 \mathrm{~cm}$. The crop was fertilized with cowdung $10 \mathrm{t} / \mathrm{ha}$, Urea $550 \mathrm{~kg} / \mathrm{ha}$, TSP $200 \mathrm{~kg} / \mathrm{ha}$, MOP (muriate of potash) $200 \mathrm{~kg} / \mathrm{ha}$. Total amount of cowdung, TSP (triple superphosphate) and 1/3 of each urea and MOP were applied during final land preparation. The rest of urea and MOP were applied in three equal installments at 15, 30 and 45 days after transplanting. Irrigation was done after application of fertilizer. Other intercultural operations and plant protection measures were taken as deemed needed. Data was collected on different yield contributing characters and yield. Recorded data were analysed statistically and means were compared by LSD (Least Significant Difference) (Gomez \& Gomez, 1984).

Table 1: Nutrients status of different fertilizers and soil characteristics of tomato planted study sites.

\begin{tabular}{lc}
\hline \multicolumn{1}{c}{ Parameters } & $\begin{array}{c}\text { Physico-chemical properties of } \\
\text { study site soil }\end{array}$ \\
\hline $\mathrm{pH}$ & 7.9 \\
Organic carbon $(\%)$ & 0.90 \\
Total kjeldahl nitrogen $(\%)$ & 0.081 \\
Total phosphorous $(\%)$ & 34.0 \\
Total potassium $(\%)$ & 0.12
\end{tabular}


International Journal of Agriculture and Environmental Research

ISSN: 2455-6939

Volume: 06, Issue: 01 "January-February 2020"

\begin{tabular}{lc} 
Total Zinc (\%) & 2.05 \\
\hline C/N ratio (\%) & 19.33 \\
\hline
\end{tabular}

\section{RESULTS AND DISCUSSION}

The results on the effect of different mulch material on the yield and yield components are presented in Table 2. There are not statistically significant among the parameter of Days to $1^{\text {st }}$ flower initiation, DAS to 50\% flowering, Date of $1^{\text {st }}$ harvest but significantly different among the other parameters. In case of plant height, there are significantly different among the different mulches. The tallest plant was recorded in water hyacinth mulches $(115.64 \mathrm{~cm})$ and shortest plant was in the treatment control i.e. no mulch $(89.17 \mathrm{~cm})$.

Table 2: Effect of Mulching on the Yield and Yield Components of Tomato Varieties

\begin{tabular}{lcccc}
\hline \multicolumn{1}{c}{ Treatment } & $\begin{array}{c}\text { Days to } 1^{\text {st }} \\
\text { initiation }\end{array}$ & $\begin{array}{c}\text { DAS to 50\% } \\
\text { flowering }\end{array}$ & $\begin{array}{c}\text { Date of 1st } \\
\text { Harvest }\end{array}$ & $\begin{array}{c}\text { Plant Height at } \\
1^{\text {st }} \text { harvest }(\mathrm{cm})\end{array}$ \\
\hline $\mathrm{T}_{1}$ (No mulch) & 37.33 & 47.33 & 62.33 & 89.17 \\
$\mathrm{~T}_{2}$ (Sawdust) & 36.00 & 46.00 & 61.00 & 95.28 \\
$\mathrm{~T}_{3}$ (Cocodust) & 35.00 & 45.00 & 60.00 & 109.98 \\
$\mathrm{~T}_{4}$ (Rice husk) & 36.67 & 46.67 & 61.67 & 109.07 \\
$\mathrm{~T}_{5}$ (Water hyacinth) & 37.67 & 47.67 & 62.67 & 115.64 \\
$\mathrm{~T}_{6}$ (Black Ploythene) & 35.00 & 45.00 & 60.00 & 98.80 \\
\hline $\mathrm{CV}(\%)$ & 4.20 & 3.29 & 2.49 & 3.10 \\
LSD $(0.05)$ & $\mathrm{NS}$ & $\mathrm{NS}$ & $\mathrm{NS}$ & 5.80 \\
\hline
\end{tabular}

Mulching significantly increased the total number of fruit/plant of tomato over bare plants. The highest number of fruit was recorded in chopped Water hyacinth mulch (28.74) and the lowest was in treatment control i.e. no mulch (22.80). Similar trend was found in single fruit weight, being the highest in chopped Water hyacinth mulch $(66.24 \mathrm{~g})$ lowest was in cocodust mulch $(53.26 \mathrm{~g})$. Length and diameter of fruit were found to be insignificant. Yield of tomato significantly increased in mulches over without mulch. The highest yield was recorded in chopped Water hyacinth mulch $(94.96 \mathrm{t} / \mathrm{ha})$ followed by rice husk mulch $(81.84 \mathrm{t} / \mathrm{ha})$ and the lowest was in control i.e. no mulch (62.86 t/ha).

Table 2. Cont'd

\begin{tabular}{lcccccc}
\hline Treatment & $\begin{array}{c}\text { No. of } \\
\text { fruit/Plant }\end{array}$ & $\begin{array}{c}\text { Individual } \\
\text { fruit wt. } \\
(\mathrm{g})\end{array}$ & $\begin{array}{c}\text { Fruit } \\
\text { Length } \\
(\mathrm{cm})\end{array}$ & $\begin{array}{c}\text { Fruit } \\
\text { Diameter } \\
(\mathrm{cm})\end{array}$ & $\begin{array}{c}\text { Yield/plot } \\
(\mathrm{kg})\end{array}$ & $\begin{array}{c}\text { Yield } \\
(\mathrm{t} / \mathrm{ha})\end{array}$ \\
\hline $\mathrm{T}_{1}$ (No mulch) & 22.80 & 55.18 & 5.41 & 4.63 & 30.17 & 62.86 \\
$\mathrm{~T}_{2}$ (Sawdust) & 25.68 & 55.63 & 5.96 & 4.71 & 34.29 & 71.43 \\
$\mathrm{~T}_{3}$ (Cocodust) & 26.96 & 53.26 & 6.15 & 4.61 & 34.40 & 71.68
\end{tabular}


International Journal of Agriculture and Environmental Research

ISSN: 2455-6939

Volume: 06, Issue: 01 "January-February 2020"

\begin{tabular}{lcccccc}
$\mathrm{T}_{4}$ (Rice husk) & 26.24 & 62.39 & 6.07 & 4.77 & 39.28 & 81.84 \\
$\mathrm{~T}_{5}$ (Water hyacinth) & 28.74 & 66.24 & 6.06 & 4.75 & 45.58 & 94.96 \\
$\mathrm{~T}_{6}($ Black Ploythene) & 25.06 & 63.86 & 6.12 & 4.56 & 38.39 & 79.97 \\
\hline $\mathrm{CV}(\%)$ & 5.45 & 3.54 & 5.00 & 5.48 & 3.67 & 3.66 \\
$\mathrm{LSD}(0.05)$ & 2.57 & 3.82 & $\mathrm{NS}$ & $\mathrm{NS}$ & 2.47 & 5.14 \\
\hline
\end{tabular}

\section{CONCLUSION}

This was the $1^{\text {st }}$ year experiment. From $1^{\text {st }}$ year, the study reveals that BARI Tomato 15 can be cultivated using chopping water hyacinth as a mulch material for higher yield.

\section{REFERENCES}

Pal A. R., Baghel S. S., Rathore, et al. Response Management for Rainfed Rice and Ricebased Cropping Systems. A paper presented at the 29th All India Annual Rice Group Meeting, Indira Gandhi Agricultural University Raipur (MP), India, 20-22 Mar 1994.

Bhella H. S. Tomato Response of Trickle Irrigation and Black Polyethylene Mulch. J. Amer. Soc. Hort. Sci. 1988; 113(4): 543-546p.

Chakraborty R. C., Sadhu M. K. Effect of Mulch Type and Colour on Growth and Yield of Tomato (Lycopersicon esculentum Miller). Indian J. Agric. Sci.1994; 64: 608-612p.

Hooda R. S., Singh J., Malik, V. S., et al. Influence of Direct Seeding, Transplanting Time and Mulching on Tomato Yield. Veg. Sci. 1999; 26(2): 140-142p.

Mehta A. P., Prihar S. S. Seedling Emergence in Soybean and Cotton as Affected by Seedbed Characteristics and Surface Mulches. Indian J. Agric. Sci. 1973; 43(1): 45-49p.

Gomez K. A., Gomez A. A. Statistical Procedure for Agricultural Research. ${ }^{\text {nd }}$ Ed. John Wiley and Sons, New York. 1984; 67-215p. 